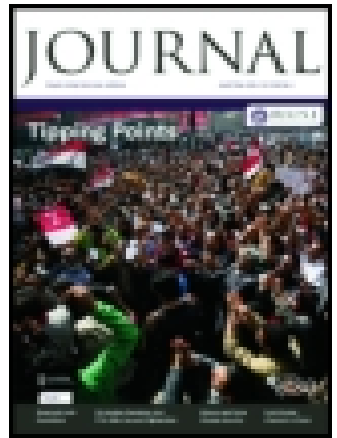

Royal United Services Institution. Journal

\title{
Horses of Different Countries, and Supply with Relation to Military Services
}

\section{Major J. Moore}

To cite this article: Major J. Moore (1905) Horses of Different Countries, and Supply with Relation to Military Services, Royal United Services Institution. Journal, 49:325, 235-268, DOI: 10.1080/03071840509418680

To link to this article: http://dx.doi.org/10.1080/03071840509418680

册 Published online: 11 Sep 2009.

Submit your article to this journal $₫$

Џll Article views: 5

Q View related articles 5 


\title{
HORSES OF DIFFERENT COUNTRIES, AND SUPPLY WITH RELATION TO MILITARY SERVICES.
}

\author{
Biy Iajor J. MOORE, Army Veterinary Department.
}

Weduesday, 7th December, 1904.

Major-General H. C. O. P'luser, C.B., Quartermaster-General, in the Cliair.

THE experience of the Boer War has shown the imperative uccessity, for all time, of a maintenance of a proper euquiry into the resources of every country with regard to its horse population, and to the feasibility of supply in time of war. To know where to go when the necessity arises, and to have everything so cut and dried that remount operations can be immediately started, is a matter of prime importance.

I am afraid you will think the subject of my lecture a very cmbracive one. It certainly is; and in the short space of time allotted to me, I can touch but briefly on many of the countrics-merely a mention in many cases. But I trust the wide subject will be the means of promoting a good discussion, eliciting opinions of those more experienced than myself. I have endeavoured to get here to-day gentlemen who have had this experience, and whose knowledge must therefore be valuable.

I wish to make a strong point of our own country and our Colonies, because I consider therein lies our first line of supply in time of need-our vast Colonies, perlaps, more particularly, to which we can always go without let or hindrance, and to which we should first give our support and custom before going elsewhere. I shall leave the consideration of the British Empire till the end of my lecture.

Some time ago I set myself the task of roughly determining the horse population of the world, and I ask you now to bear with me in the matter of a few figures. Indeed, I fear that throughout the lecture I shall have to quote statistics more or less, but I promise that I shall bore you as little as possible with them.

I calculate that the equine population of the world is close on $80,000,000$. The United States Department of Agriculture, a very go-ahead and up-to-date Department, computes the number at $75,000,000$.

vol. XIIX. 
By continents, I estimate the number approximately as follows :-

$$
\begin{aligned}
& \text { Europe - - - - } \quad \text { - } \quad \text { - } 40,000,000 \\
& \text { Asia - - - } \quad \text { - } \quad \text { - } \quad \text { - } \quad \text { - } 11,000,000 \\
& \text { Africa - - - - - . - - - } 1,250,000 \\
& \text { Ancrica }\left\{\begin{array}{c}
\text { North America, incluling } \\
\text { Canada and Mexico - - } \\
\text { Central and South America - }
\end{array} \quad \begin{array}{r}
\mathbf{1 9 , 0 0 0 , 0 0 0} \\
6,000,000
\end{array}\right. \\
& \text { Australasia - } \quad \text { - } \quad \text { - } \quad \text { - } \quad \text { - 2,000,000 } \\
& 79,250,000
\end{aligned}
$$

Of the 40,000,000 horses in Europe, there are in:-

$$
\begin{aligned}
& \text { Russia (European Russia) - - - - 22,096,000 } \\
& \text { Germany - - - - - - } \quad-4,184,000 \\
& \begin{array}{lcc}
\text { Austria-IIungary } & \left\{\begin{array}{ll}
\text { Austria } & 1,711,000 \\
\text { Hungary } & 2,309,000
\end{array}\right\} & 1,020,000 \\
\text { Frauce - - - } & - & -
\end{array}
\end{aligned}
$$

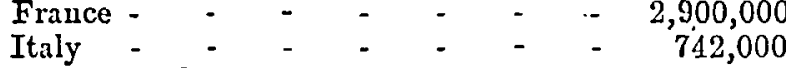

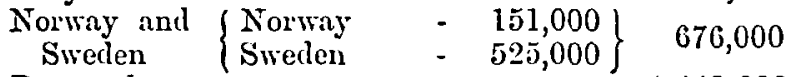

$$
\begin{aligned}
& \text { Deumark - } \quad \text { - } \quad \text { - } \quad \text { - } \quad \text { - } \quad \text { - } 449,000 \\
& \text { Holland - - - } \quad \text { - } \quad \text { - } \quad \text { - 285,000 }
\end{aligned}
$$

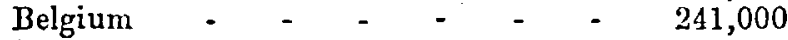

$$
\begin{aligned}
& \text { Switzerland } \quad-\quad-\quad-\quad-\quad-\quad-109,000
\end{aligned}
$$

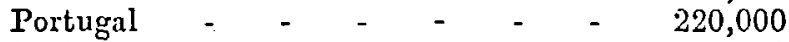

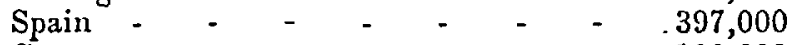

$$
\begin{aligned}
& \text { Greece - - } \quad \text { - } \quad \text { - } \quad \text { - } \quad \text { - } \quad \text { - } 100,000 \\
& \text { Turkey in Europe - . - - } \quad \text { - } \quad \text { - } \quad \text { - } \quad 300,000 \\
& \text { Bulgaria - - - - } \quad \text { - } \quad \text { - } 344,000
\end{aligned}
$$

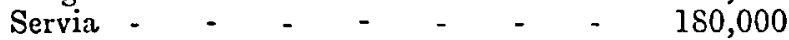

$$
\begin{aligned}
& \text { Roumania - } \quad \text { - } \quad-\quad \text { - } \quad \text { - } 864,000 \\
& \text { The United Kingdom of Great Britain } \\
& \text { and Ireland } \quad-\quad \cdot \quad-\quad-3,000,000
\end{aligned}
$$

\section{Russia.}

It will thus be seen that Russia has by far the greatest number of horses in Europe-23 millions out of a total of 40 millions. Add to this scveral millions more at her command in Asiatic Russia and Mongolia, we see her wealth in horse-flesh, making her independent of any other country, a great source of strength in time of war. Yet with all this strength she jealously guards export. Being so much beforo the public at present in her war with Japan, it will be interesting to recount her resources a little more fully than her neighbours.

Perhaps in no other country is more attention given by Government to the breeding of horses than in Russia. There are five Imperial and seven Military Studs. Of the Imperial Studs, there is a large one at Khrénovoi in the Don District, purchasod from a descendant of the founder of the Orloff breed of trotting horses. This stud consists of saddle horses, trotters, and English thoroughbreds. The best mares lere are said to be those got-by $A$ rab sires from English mares. Another large stud is the Belevodsk, embracing four establishments, viz.: (a) Derkoulsk, a very old stud, turning out carriage horses; (b) Streletz, devoted to Arabs; (c) Limarveo, also Arabs; and 
(d) Novo Alexandrov, for half breeds. A third small stud is at Janow for half breeds; a fourth at Orenburg for the brecding of Kirghiz, or Steppe horses.

Of the seven military studs:-

4 are in the province of Kharkoff, for half breeds chicfly.

1 is in Voronej, for trotters and heavy draughts.

1 in Don, for Steppe and Oriental breeds.

1 in Poland, for half breeds.

The above will show that there is a considerable infusion of English thoroughbred and Arab blood in Russian horses.

Private studs are very numerous. In the Don District alone there are 866 private studs, with 3,100 stallions and 101,000 mares, more than in all the rest of Russia.

Under the dircetion of the General Stud (Government) there are 27 stables or depots with 23,000 stallions for covering purposes in different parts of the country, and great improvement in local breeds has resulted from these.

The country is essentially one of riding and light draught horses. The Cossack district of the Steppes, with its breeds of Don, Kalmuck, Khirgiz and others; the provinces of Poltava, Kherson, Kieff, Podolia, Vollyynia, and Bessarabia, in South-Western Russia, and Poland produce the riding horses. The provinces of Voronej, Orel, Koursk, Riazan, Toula, and Tambov produce the draught horses.

Compared with those of other countries, Russian horses generally are small, running chiefly from 14.0 to 15.1 . 40,000 were obtained for mounted infantry purposes during the latter part of the Boer War, and were well reported on. They possess great substance, good back and loins, deep girths, and are active and very hardy. Their common fault is sickle-shaped hocks. The Don horse is inclined to be long-backed, and shows travel sooner than lorses from other parts. The prevailing colours in Russian horses are dun, chestnut, and grey, all real hardy colours. Russian cavalry remounts are chiefly drawn from the Don District, though the twelve regiments of Horse Guards are liorsed from Imperial studs, as Steppe-bred animals are not strong enough to mount the men. Polish horses are not good; they are lat-sided, long-backed, and weak. There aro threo very hardy indigenous breeds in Finland; the best of which is the Savolaskolkarel, 14 liands, strong, with short legs, but rough for riding. $\Lambda$ common colour of this breed is a cream with black legs, mane, and tail (Isabelle).

The animal of all others in Russia that would take our fancy for mounted infantry purposes is the semi-wild horse of the Steppes, the Irhirgiz pony, a nomad type, numbering several millions. They are found in Orenburg and Turgai, Akmolinsk, Semipaltinsk, and Semirichia of Asiatic Russia. Seldom over 14 hands, robust, straight back, broad quarters, rather short in forehand, short hard legs, small and hard hoofs, short coat in summer, thick coat in winter, cream, roan, light chestnut, dủn, flea-bitten grey, can go for two or three days without water, and do long journeys, price $£ 6$ to $£ 8$ in his own district, sums up his description and character. Some of these found their way to South Africa during the war, and their journey to the port of $\mathrm{cm}$ barkation, Fiume, is most interesting-six or eight days' journcy by road to Orenburg, there entrained and taken to a station on the 
Volga (either Samara or Saratov), then placed in open boats and floated down the Volga four to seven days to Tzaritzan, thence by rail to Fiume, 3,000 miles, one month's travel. And of all Russian cobs they presented themselves for purchase in the best condition.

Of other semi-wild horses of the Steppes, I may mention the Kalmuck breed, living between the Volga and Ural, ugly horses with heavy heads; also the Bashkirs, 600,000 in number, 14 lands, heavy liead, thick coat, short back, good legs, used by Ural and Orenburg Cossack regiments. Winter tells heavily on Steppe ponies, many dying, especially those under five years of age, so that the remainder are the survival of the fittest.

Like most other European-Continental countries, the horse-breeding industry of Russia is subservient to military requirements. A census of horses fit for the Army is taken every six years. For this purpose and for requisition of horses in time of war, each civil district is divided into Remount Circles, to which an official known as Director of Horse Census is appointed. After enumeration by this official the horses are inspected by specially detailed officers, and those fit for service are registered and classified according to the branch of the Service for which they appear suitable -cavalry, transport, pack. Copies of mobilisation tables are kept by local, authorities and Director of Census. On mobilisation, these horses would be called up by the Director of Census, and for acceptance or otherwise would be examined by a board. No owner is compelled to part with more than half, and if he parts with one voluntarily, ho is exempt for tro from compulsory purchase.

This enrolment for probable military demands would in a great measure be prohibitive of exportation in large numbers, especially. when good animals are likely to be taken; still, the country is sufficiently stocked with riding horses of a small size to be a field for purchase by a belligerent Power in time of war.

That exportation is allowed in time of peace is shown by the number of Russian ponies brought into England annually.

Russia could easily furnish eight horses to every man in its Army. Most other countrics could find but two.

\section{Germany.}

According to the census of 1900 there were in Germany $4,184,099$ horses, of which 2,913,003 were credited to Prussia. The principal horse-breeding districts are East Prussia, Hanover, some parts of the Province of Posen, the Duchy of Oldenburg, and Mecklenburg.

The good material of the country is appropriated almost entirely to supply the demands of military authorities, and the remainder may be said to be unfit for military purposes. Much has been done by the German Government to improve horse-breeding, but still a great part of inland demand has to be covered by importation; the extent of this will be scen from the following import returns:-

So that Germany cannot be considered of any use to us as a field for remount supply. 
$£ 190,000$ is spent annually by the Government in horse-breeding operations. Over 2,600 stallions of all grades, from the thoroughbred to the heavy draught, arc maintained in rural studs and covering stations. Most of these are bought, though some are bred in State breeding studs, of which there are four, the largest being at Trakenen, in East Prussia. The Trakenen horse is now bred to type. He is an outcome of thoroughbred and hackney strains, is a low, long, black horsa, 16 hands, with good limbs, beautiful head, rather long in the back. $\mathrm{He}$ is very gentle, and especially useful for harness work.

Hackncy blood flows in the veins of the majority of German horses. The Hanoverian horse, also bred to type, is of imported hackney ancestry. This loorse is a dark brown or chestnut liarness horse about 16.1, with great limbs. The province of Oldenburg has long been famous for coach horses. In the Rhine provinces, Westphalia and Saxony, Belgians, Clydesdales, and Shires are bred.

The chief aim of the Government Stud Department is to provide remounts for the Army. The best remounts are found in East Trussia, Hanover, Oldenburg, and Mecklenburg, purchased at 3 years old, and kept in remount depôts for another year; the average price is $£ 41$ los.

Germany buys on an average 21,000 horses from Belgium ammually, taking, it is said, the best of the Ardennes horses.

All lorses, with the exception of those belonging to reigning families, foreign cmbassies, Government officials requiring them for their work, physicians, veterinary surgeons, and postal service, are liable to be requisitioned in time of war, and for this end an inspection takes place every 18 montlis. Parish, county, and provincial lists are prepared, the horses being classified according to suitability for different branclies of military service.

\section{France.}

Very little need be said of France from a supply point of view. The country really requires all it possesses. The total number is cstimated at 2,900,000 in France, 205,000 in Algeria, and 35,000 in Tunis, her two principal horse possessions. Her war effective in horses is 577,620 , the peace effective being 122,700 . These are large numbers to be found out of a comparatively small total. Between 450,000 and 480,000 extra would be required to start a war, and a difficulty in meeting requirements, especially later requirements, would be experienced. Mobilisation experiments by requisition have at different times been made as tests, and have not been satisfactory. To try and encourage horse-raisers to produce a military horse a large special annual sum has been allowed since 1897, enabling remount service to pay higher prices than heretofore, condition for such higher price being a certificate from the seller of a horse stating that the animal is of French origin. There are twenty-two studs administered by the Department of Agriculture, whose object is to furnish good sires for improving the breed of French horses, especial attention being paid to stallions suitable for producing military horses. "Of these I may mention Tarbes, in the Department of Hautes Pyrénées clarged with distribution of English thoroughbred, A rab and AngloArab stallions; Le Pin, in Normandy, where Norman, Pcrcheron, and 
qualified trotters (graded Hackneys) are used; St. Lo, also in Normandy, chicfly Norman and trotters.

The principal horse-raising districts in France are:-

1. The Departments of Basses and Hautes Pyrénées in the neighbourhood of Pau and Tarbes where light riding horses, 14.2 to 15.1 suitable for light cavalry and infantry are chiefly bred.

2. Normandy, the home of the Norman horse, chiefly draught, heavy riding (heavy cavalry and artillery) and a proportion of heavy draught, and

3. Brittany (Finisterre and Côtes du Nord principally), with

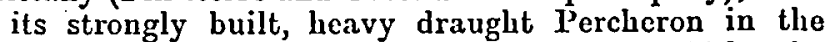
North, and the small hardy Brittany pony, 14 hands, in the South.

$A$ horse census is taken ammually, and a register of all horses and mules fit for military service is lept, the branch of Service to which each horse is assigned being stated.

The military maintains two breeding farms in Algeria, furnishing Arab and Barb stallious to Goverument studs in Algeria and Tunis.

Algeria is the cradle of the Barb horse, the points and quality of which are well known. He is essentially a riding horse, most suitable for mounted infantry, height 14.1 to 15 hands. The Department of Constantine contains the most, the Department of Oran a lesser number, and the Department of Algiers the least number. They cost the French Government $£ 24$ for troop horses, $£ 35$ for officer's horses.

Tunisian breeds vary much in size, quality, and appearance. They are not of much account. The French Government buys the best.

\section{Austria-Hungart.}

So much was writton and said abont the Hungarian horse during the Boer War that he is already familiar to most of us. Bought by good judges, his appcarance promised better success in the field, but events proved him soft, lacking in stamina and a subject of laminitis (the sequel of exhaustion).

Associating cause with effect, I have often asked myself the reason of this failure in our Hungarian friend, in fact in all horses that were weighed in the South African balance and found wanting, and I find that apart from the transportation from a northern zone to a southern zone, or from one country to another, thereby necessitating acclimatisation, the horses that proved themselves the worst campaigners were those that were not grain.fed animals in their own country, and therefore had no bottom in them to begin with. The majority of Hungarian farmers give little or no grain to their horses. Lucerne is cultivated to a very great extent in the country, and this, mixed with other grasses, made into hay, forms the staple food for the steck. The Argentine pony, another animal badly reported on, is entirely grass fed, and will not look at grain for some time. The Australian horse generally is another example.

The range. horses of North America were saved from a similar fate by a cast-iron constitution that had survived the hardest of winters, and by a grain diet for some time prior to shipment. On 
the other hand, the horses that withstood the vicissitudes of the campaign best were those that were well nourished from a grain diet, c.!. the London 'bus horses.

Austria-Hungary is well stocked with horses, there being $1,711,000$ in Austria, 2,309,000 in Hungary, making a total of 4,020,000.

Hungary is essentially a light horse country. Over $£ 230,000$ is spent annually in horse-breeding operations. Government maintains four state breeding studs, the principal of which is Mezoleyges, and has nearly $3,000^{\circ}$ stallions scattered about the country. All the peasants breed extensively, 99 per cent. of the stock being bred by this class.

The ground-work of Hungarian-horses is English thoroughbred, Arab, Anglo-Norman (Nonius), Lippieza (Austrian) blood (a mixture of Spanish and Arab), and Norfolk trotter strains. The average height is 15 to 15.1. Good-looking, glossy coats, good manners, rather light but clean legs, well set on head, back inclined to be long, shoulders straight, narrow in front and behind, is a general description. All go in harness in pairs in light four-wheled carts; the foal at a fortnight old may be scen strapped to its mother's breast harness. They are generally put to light harness at 2 years old. The Hungarian peasant does not ride.

$£ 140,000$ per year is spent on horse-breeding operations in Austria proper. Over 2,000 stallions are distributed througliout the country, and no fewer than thirteen different breeds are in use. The horses are chiefly of a leavy draught and carriage class. Encouragement is given to retain local breeds pure. In the mountain regions the Pinzauer horses, a splashed coloured, small, stroug, hardy breed, are well spoken of for draught and pack.

In addition to two state studs, there are two special breeding establishments at Kladrub and Lippieza, where carriage horses are bred. The Kladrub horses are large showy animals, chiefly used for royal carriages on state occasions, and are of Spanish and Italian descent. The Lippieza horses are handsome, hardy carriage horses, 15 to 16 hands, long bodied, and short legged. They are of Spanish, Italian, and Arab strains. Austria proper affords no feld for remount operations.

There is no inspection in peace time to determine the fitness of horses for service on mobilisation. The Minister of Defence allots so many to be furnished from each province.

Remounts are usually bought direct from owners in the autumn at 31 ycars, prico being $£ 27$. $\AA$ reserve of over 10,000 trained ricing lonrses is maintained, the horses being farmed out with responsible people, and called up for 6 weeks' training of reservists each year.

Under heading Austria, I should like to mention Bosnian ponies, found in great numbers in the mountain districts of Bosnia. Though ugly, they are good, docile, hardy, substantial, blocky ponies, with good backs and broad quarters, and useful for pack purposes. Their usual load is 2 cwt. up and down the mountains. Their average lieight is 12.2 to 13 hands. They were bred originally from Arab blood, introduced by Turlish officials. About $£ 10$ or $£ 12$ would land them in England-probably 1,500 available.

An interesting feature about this pony is, that often his saddle is not taken off for 5 or 6 years at a stretch. It projects in front of the shoulder blade, and rests on the neck. The omner sits on this projection, and the load is carried on hinder part. 
ITALY.

Italy is not an important liorse-producing country; in fact, the annual imports, chiefly from Hungary, amount to 38,000. For many years it was impossible to obtain the required number of suitable remounts for the Army without having recourse to importation, but by the institution of Government stud farms and the careful controlling of the quality of the stallions, sufficient remounts can now be obtained, and a gradual improvement in the breed of horses is taking place. Government maintains about 600 stallions; the majority aro full or half-bred English or Arabs, some hackneys, Clydesdales, and Brabants. It will be remembered that Melton, the Derby wimner of 1885, went to Italy.

All animals 14.1 and over that are considered fit for military service are registered by local authorities. They are periodically inspected, classified, and have their value assessed by military committees.

The ordinary Italian horse is a weedy, undersized animal, prematurely exhausted by overwork at too early an age.

The Maremma District of West Tuscany (Province of Grosseto) is the best. The Maremma horse is a stout, ugly, wiry animal, about 15 hands, bred on the wild system. They apparently enjoy great favour in the Italian Army, and many of the horses used in Rome, especially in omnibuses and cabs, hail from this district.

In the Island of Sardinia is a small, hardy, quick, and easily trained horse. The Italian Government sends an Army Commission there every year, and the best of the colts, 14 hands and over, are bought up young. Anything seen over six years old is worn out.

Of other European countries I need say very little. Nono of them would be of any value to us as a source of supply.

\section{Norway and Sweden.}

Scandinavian ponies are rough, sturdy, docile animals, the original stock still found in the forest lands of the North being prolably of Tartar origin. Great improvements in breeding are taking place in the south and south-west of Sweden by importation of English hlood stock, and for draught purposes, the Clydesdale, tho Ardenne, the Shire, and Percheron.

\section{DenJiark.}

Danish horses are good, light draught horses, long in the back as a rule, and slow, but, having good legs, they stand a good deal of knocking about. Germany is reputed to take 16,000 of them annually, many of then for omnibus work.

\section{The Netherlands.}

Holland is not a horse-breeding country. The native horse is wanting in stamina, and remounts for Army are obtained from Ireland.

\section{Belgiust.}

The type of horse generally raised in Belgium is a heavy animal, known as the "Flemish Horse" in his heavier form, and as the 
"Ardennes Horso" in a somewhat lighter form. The latter, bred in the Ardemnes district, is a strong; compact horse, admirably suitable for artillery and draught purposes. The artillery and transport horses of the Belgian Army are all drawn from this district, the cavalry horses being imported. Germany buys on an average 21,000 horses from Belgium annually.

$\Lambda$ curious and interesting feature of export returns of the United Kingdom is that about 23,000 horses are annually shipped to Holland and Belgium, export prices being. quoted at from £ll to $£ 14$ respectively. This exportation is mainly for food. Perchance, our old familiar friends, $\mathrm{B} 22$ and $\mathrm{X}$ Battery 64 , return to us in altered form.

\section{Srain.}

The horses of Spain, descendants of Barbs, as a rule are honost little animals, but lack stamina. They are only suitable for light draught and mounted infantry. The Spanish Remount Commissions take the pick, purchasing, at 3 years old, at $£ 27$. They are chicfly bred in the pasture lands of Andalusia, Estremadura, and La Mancha. They are notable as being the progenitors of the horses of the New World.

\section{Pontugal.}

Horse-breeding in Portugal is at a very low ebb, and 75 per cent. of the horses of the Army are obtained from Spain.

\section{Switzerland.}

There are not enough horses in Switzerland to supply the needs of its own Army, and about 800 are imported annually, chiefly from Ireland, Northern Germany, and Hungary. These are issued by remount depôts to the men of the Elite, who pay half the appraised value. They use them in their private occupations, usually taking great care of them, and have 10 per cent. of what they paid refunded annually. The system is quite unique.

\section{Roumania, Bulgaria, Servia, Greece.}

Roumania and Bulgaria obtain most of their Army horses from Hungary and Russia; Servia from Hungary. The native ponies of these countries are only fit for pack and train purposes. Grece also obtains its supply from Hungary.

\section{Ottoman EMrite.}

The Turk is not given to furnishing statistics, and therefore it is not possible to estimate the number of lorses in the Empire, particularly as regards Turkey in Asia, which is the only portion worthy of consideration from a remount point of view.

The stamp of horse to be found throughout the Turkish Empirc is best suitable for light cavalry and mounted infantry, especially the latter. In the Turkish Service many of the cavalry and nearly all the artillery are from Hungary and Russia. Local horses have been tried for artillery in Turkey in Asia, but they are inçapable of drawing heavy weights over rough ground. 
Speaking generally of ponies of European Turkey, they are weedy and undersized, and not worth purchasing for military service. Asiatic Turkey affords a much better field, the best districts being the provinces of Elzeroum, Van, and Diarbekr in Eastern Turkey in Asia; the provinces of Sivas and Angora in Northern Anatolia; the Vilayets of Smyrna and Ionia in Western Anatolia; and in Syria and Mesopotamia.

Roughly speaking, the breeds are:-

1. Kurdish, from Erzeroum, Van, Diarbekr, and Mosul.

2. Circassian, from the province of Sivas.

3. Anatolian, from Angora and Smyrna.

4. Arabs, from Mesopotamia and Syria.

The Arab is so well known to us that a description is unnecessary. He is by far the best. Ireights run from 13.1 in the well-bred Nejdi of Arabia to 14.1 and 14.2 of the Aleppo and Urfa districts of Northern Syria. The price in his own country is on an average $£ 20$. Ereeding is all in the hands of different nomad Arab tribes.

The Kurdish horse, bred by Kurdish tribes, is about the same size as Arab, but stouter, not of such high class, and cheaper.

[Kurdistan is ethnographical, rather than geographical nomenclature, and comprises a large belt of country partly in Persia and partly in Asiatic Turkey, with Mosul (site of ancient Ninevah) for its best known town.]

With regard to Asintic Turkey as a source of supply, it is very doubtful if the country is sufficiently attractive in point of available numbers and quality to admit of much purchasing. $A$ drawback is the long distances animals would have to travel by road to a port of embarkation, there being few railways in the best horse districts. For many years Syria, witl Beirut as the shipping port, has been the purchasing ground for Egyptian requirements; but the drain on the country has diminished the supply, and at the outside 2,000 per annum, 14 hands and upwards, would be all that could be obtained. However, with Alexandretta as a collecting and shipping port, better results miglit accrue. From here, Northern Syria, Mesopotamia, and Kurdistan, even into Persia, could be tapped, working along the caravan routes by Aleppo, Urfa, Mardin, Diarbekr, Mosul, and Suleimanieh. About 3,000 could be obtained along this line, but the price at port of cmbarkation would probably be $£ 30$. It would also be possible to draw Circassian lorses from the province of Sivas to Alexandretta, thus adding to the numbers; and in this matter an annual migration from the uplands of Sivas to Adana and the Sicilian plain for the winter would be found rather convenient.

It would be waste of time drawing animals by way of the Black Sea. The state of society in the provinces bordering the TransCaucasus is such that owners find their horses too useful to part with. Besides, there are 63 regiments, 32,000 horses, of the Hamidiel or Irregular Militia Cavalry of the Kurdish tribes, and after their requirements are fulfilled, nothing remains; their horses are all branded.

If shipments were required east, by way of the Persian Gulf, the same caravan route previously mentioned could be worked on, Mosul being the principal purchasing centre, Busra being the port of embarkation. There are annual shipments to Bombay from this direction. In normal times cach of the Bombay market dealers has from 
200 to 500 collected for shipment; but these numbers could be augmented in time of war. It is considered that remount operations from the Persian Gulf would be disappointing and a tedious process. Mrab horses could perhaps be bought cheaper in Bombay. However, shipments might be supplemented from Persia, drawn either by way of Bagdad or Bushire.

\section{Persia.}

The Persian horse is very nearly related to the Arab, but is more slender in build, though slightly taller as a rule. There are, however, other brecds in Persia, viz., the Turkoman and mixed Turkoman and Persian in the north-east; the Karadagh, a Cossack breed, in the north-west, near the Russian border; the IKurdish horse of Kurdistan; and the Arab in the west and south-west. The best districts for horses are the province of Khorosan and the Kermanshah and IIamadan districts of Kurdistan. The brceding is chiefly in the hands of nomad tribes, who follow the same metlods of breeding as Arabs in Nesopotamia, but in all these districts the numbers available are less than formerly. Speaking generally, the horses are mostly of the native Indian cavalry or mounted infantry. type. All purchases would be entire; mares arc never sold and seldom ridden. $£ 16$ or $£ 17$ would buy a good native cavalry horse, and ponies, 13.3 to 14.1 , that rould do for mounted infantry, would cost $£ 10$ to $£ 12$, but the cost of transportation to shipping points would be an extra $£ 10$. There being no railways in Persia, all animals would have to go by road, and travelling would have to be done during winter months on account of the scarcity of water.

It is estimated that Persia, exclusive of Khorosan, could supply 4,000 horses. Khorosan could supply 3,000 horses, 13.3 to 14.1 , and about 7,000 baggage ponies, 12.3 to 13.3 . Khorosan animals could go by march route to India, ria Quetta.

\section{Cinjese Eupine.}

Of other Asiatic countries, time will only admit of my making very bricf reference. I have already alluded to the horses of Asiatic Russia, with its large numbers of ponies bred by different tribes. Chinese Turkestan-for the most part low desert-is not rich in horses. Mongolia is, however, well stocked with ponies of sorts. Intcrest is to some extent attached to it at present on account of tho Russo-Japanese War. It is also more accessible and nearer ports of cmbarkation. Nomad Mongols devote their attention to the breeding of horses, one of the uses of which is for the production of koumiss, or fermented mare's milk, the staple driul of these nomads.

The Mongolian pony is from 12.1 to 13.3 in height with an occasional 14.1. They are hardy, can live in the open in all kinds of weather, and are up to great weight compared with their size. Though trained in a rough way, they require a good deal of handling and riding before becoming handy and reliable; they are very slow. In 1900 the Indian cavalry, mounted on 14.0 to 14.2 Arabs, rode down the Chinese on Mongolian ponies in a very short distance.

The best and largest comes from the extreme north, especially round Lake Kulan, enst of Urga. 
Dolon Nor or Kalgan are good collecting centres; probably 1,000 conld be got at the latter place. Large numbers are brought down to China during the winter every year, and the average price in l'cking or Tientsin is about $£ 410$ s.

Enormous heru's of small ponies, useless for military requirements, exist in Southern Mongolia (Gobi desert). Their hoofs are worn very short, and their teeth are also worn down with grazing on stony ground.

What is termed the "Chinese pony" is really the Mongolian pony. There is a China pony proper, however, existing in the southern provinces. It scarcely reaches 12.1 , and is of the same breed as ponies of Annan, Siam, and Burmah.

\section{JAPAN.}

I come now to Japan, around which, in her gigantic struggle with Russia, so much interest centres. It is a curious fact that in the present war, Russia,. with her enormous resources in horses, Japan, with her poverty in the same dircetion, we hear and read so little of the part taken by horses. Yet I suppose requirements and expenditure must be enormous. Where Japan draws her supply from has not been stated. In the year 1898. (the last quoted census) there were $1,587,891$ horses, and the Goverument experienced great. difficulty in providing horses for the Army. The animals of the country are poor-looking ponies, 13.2 to 14.2 , witl straight shoulders, narrow chests, drooping quarters; but they are tough, and need little care.

Threc principal types are noted :-

1. The Kiushiu-Satsuma horse, which has a strain of Arab blood.

2. The Yezo horse, said to be the best, and which forms the chief remount.

3. The Nambu horse, a capital draught animal.

It was remarked of Japanese cavalry horses with the Allied Forces in China in 1901, that they were an uneven lot of country breds, 14.1 in height, with large plain lieads, heavy chests, long legs, all stallions with-a distinct cross of American trotting blood. They looked hardy and useful.

The transport animals were all stallion ponies. They were harnessed to a light framed cart with low wheols, a man to each pony. They worked hard and kept in good condition, but screamed and fought along the line of march.

However, the Japanese Govermment, alive to the military requirements of the country, have of late years made great efforts to repair the deficiency, both as regards the number and quality of the horses used for military purposes.

With a view to improving the breed of horses generally, studs have been established, and prizes awarded to breeders rearing good stock. A law was passed providing for the establishment of guilds in various urban and rural districts. These guilds are to a large extent self-governing bodies, but under Govermment restrictions. The Goverument reserves to itself the right of buying at market prices any horses fit for its own use. All persons wishing to engage. in horse-breeding must form themselves into guilds, and no person is 
allowed to become a horse or cattle dealer without first obtaining a certificate from the police, and must keep a record of his transactions. Stallions and mares are rigidly inspected as to their suitability for breeding purposes, and must be registered. American, Hungarian, French, Persian, and English are among the stallions imported. A glance at the agricultural returns of Great Britain shows that in 1900,18 stallions at $£ 309$ each, and 5 mares at $£ 227$; and in 1901,17 stallions at $£ 385$, and 3 mares at $£ 150$, were obtained.

During the China-Japanese War in 1894-95 the Japanese used a small number of Corean ponies for pack transport. The French also used these ponies in 1900 . They are very hardy, sure-footed, 9 to 12 hands high, and only used for pack work. They bear the name of being pugnacious, and would require Corean horse-keepers to accompany them, as they lnow best how to manage them. Their value is $£ 4$ or $£$.

The island of Quelpart, to the south of Corea, is reported to contain a considerable number of ponies of diminutive size.

\section{THE NEW WTORLD.}

I will now ask you to cross the Pacific with me to the Americas, and consider the horses found there. Having lived in the United States for fifteen months, and visited Canada, Mexico, and the Argentine, I can speak with a fair amount of confidence.

It is idle of me to recount the tremendous progress the New World has made since its discovery in the .15th century, or to speak of the forcmost position it occupies to-day-an object-lesson to parent countries. I wish only to mention that horses (and I should also like to add mules) have participated in this general progress, until now we find here the best field for supply, the most useful classes of animals, and the greatest available numbers in any portion of the globe. And it is every day getting better.

The trade in all kinds of stock is enormous, and the people are not those who drive custom from their doors.

For anyone who is fond of history of horse population, development of breeds, etc., there is ample scope here for much interesting study. Different invasions and occupations by European Powers have all left their traces. No greater mark has been nade than by Spain when at the zenith of her power in the 15th century, and it is wonderful to note the extent of Spanish horse invasion. Freed from the restraint of man, escaped to the prairies when Spanish settlements were destroyed by Indians, horses roamed wild for hundreds of miles, right, I may say, from the Pampas of the Argentine, through Nexico, to the Rocky Mountains in British Columbia, forming original stock. To this invasion dates the small horses (Criollio ponies) of the Argentine, the horses of other South American countries, Mexico, and the Cayuse, or Indian pony, in the Western States of America and Western Canada.

To-day the Americans possess 25,000,000 horses, distributed, roughly, as follows:-

North America, including' U.S.A., Canada and Nexico - - - 19,000,000

Central and South America - _ . - 6,000,000

$25,000,000$ 


\section{United States of Ajemica.}

By far the greatest number of the above-at least 17,000,000are located in the United States of $\Lambda$ merica, and it is of this country that for the present I wish to speak. Canada I purpose dealing with afterwards, under the heading of "Horses of the British Empire."

In point of numbers and general excellence, the United States in a matter of horses scarcely has its equal. Beginning in the early days of colonisation with importations of European stock, chieny from England, the Netherlands, and Canadians of French origin, subsoquent crossings with the Englisl thoroughbred, and grading up vith home productions, the present day American horses may be considered distinct in types, and creations of the country. Even the original Cayuse or broncho was improved in the early history of American horse-breeding by the use of thoroughbred and hunter sires, the progeny being small, but of excellent stamina.

Increase of population and prosperity of the country causes a constant large home demand, and the horse industry flourishes in consequence. A fmancial panic in 1893 caused for a time a depression in horse-breeding, but during the past few years the trade has steadily increased. At the present time the visible supply of desirablo horses for all purposes of four and five years old is estimated at about 100,000 , hardly, some say, enough to supply the average demand, but young animals are much more plentiful throughout the country, and with the increasing demand and interest that has been raised in breeding good animals which can readily. be sold, the supply should be more ample in the future.

We are all perhaps familiar with the American trotting horsemore properly designated by the name of Standard Bred. The average American, particularly in the Eastern and Central States, prefers driving to riding. Everything lends itself to this-roads, convenience, cxcellent light vehicles, pleasure of driving, etc. The Standard Bred trotter or pacer is a highly specialised roadster, eligible for registry in a trotting register, and the result of jears of breeding for the sole purpose of increased specd. The progenitor of this class is an imported English thoroughbred horse, Messenger by name, and more particularly through a horse named Rysdyk's Hambletonian, foaled in 1849. This latter liorse is reputed to be the sire of 1,300 foals, 40 of which took records.

An idea of speed may be gained when $I$ mention that Lou Dillon, a mare, 15.1 mile. Needless to say, there is a good demand for this trotting strain, the speciality of America. Leggy, light of bone, wide action behind, narrow to follow or to meet, upright and loaded shoulders, frequently cwe-necked, not always fine about the throat, ears, and head, frequently sloping and even flat quarters, light in ribs, and angular all over is the usual description-distinctly a light harness type. They are usually of most excellent temperament.

Other strains less highly specialised as trotters form the bulk of the American horses. Though from an English point of view they appear more of a light harness type, having low and loaded shoulders, and usually a short neck, yet they have excellent backs for riding purposes and good legs. From this class the American Government draws 
its remounts, 15.1 to 15.3, and from it also the British Government obtained horses of a lesser height during the Boer War. There is a great demand for this animal for city and country trade.

Under the American Saddle 'Horse Breeders' Association, great endeavours are made to maintain an American saddle horse as a type. The progenitor of this strain was a thoroughbred stallion named Denmark, foaled in 1839, and brought to Kentucky. During the Civil War stock of this Kentucky strain performed most wonderful marches. When Morgan marched from Sparta in August to surprise a garrison at Gallatin, he accomplished the distance of 90 miles in 25 hours, and afterwards, in the Ohio raid, after two weeks of severe Diarching be covered 94 miles in 35 hours without halting, the greater number of his command of 2,100 performing it without flinching. Whether the present day American horse with its greater admixture of trotting blood can do it, it is difficult to say.

A demand for the best saddlers, 15.2 to 16.2, as lunters, now exists, riding to hounds gaining in popularity in the country.

About the year 1875, through the influence of State and National Association, interest was aroused in the breeding of heavicr horses, Hackneys, Clydesdales, Shires, Normans, Percherons, Belgians, and French coach breeds being imported. This infusion of new blood resulted in greater size and better bone of the horses in general use on the farm and for sale in the market.

The breeding of thoroughbreds is rapidly assuming great proportions, and we often see American horses competing on the English turf. Racing in the States is unique, inasmuch as meetings are of 30 consecutive days' duration, or even more.

The principal breeding States for high-class horses of all kinds are Illinois, lowa, Minnesota, Wisconsin, Michigan, and Indiana. These States supply Chicago and the cast with their best horses, and the types produced are drafters, expressers, 'busers, farm chunls, coachers and drivers, high-class harness horses, and saddlers. Chicago is practically the centre of the industry; to it most of the animals find their way for sale. In these States and Kentucky many of the show horses and matched carriage horses are standard bred trotters.

Missouri and Kansas produce a large number of horses of an inferior type to the above, usually of the roadster and saddle classes, or for light farm work. Many are sent to the plantations of the Southern States. Better classes are very suitable for military servicecavaliy and mounted infantry.

Texas bears a great name for horses, and produces them in great numbers. The best class, and the most numerous, is the cob, 14.2 to 15.0 .1 , lighter in build than the average horse of the same lieight in Great Britain, but showing more breeding. $\mathrm{He}$ is, as a rule, ugly, long, narrow, and flat-sided, but his speed, hardihood, and endurance are phenomenal.

Comparatively few horses are bred in the Eastern States, the small farms in those older States not being able to compete with the large farms and ranches and cheap land of the newer Westem States.

The North-Western States of the Union, viz., Washington, Oregon, Idaho, Montana, and Wyoming, present a large brecding district, and is the home of the "range loorse." 
Range or ranch horses of the present day comprise:-

1. Ponies, standing up to 14.2 , descendants of the ancicnt stock that is known by the names of Cayuse, Indian pony, or mustang; of great endurance, useful for herding cattle, and furnishing good material for polo.

2. Saddlers and drivers, 14.2 to 15.2 , crosses of coach, standard bred, and thoroughbred, and representing what the range is capable of producing in the way of horses.

3. Draught grades, chunks, 15 hands and upwards.

They are all branded. The prejudice against a branded horse is not so strong as formerly. The evil disposition of the old range horse or bronclio, and his individuality, is being greatly improved by the more progressive ranchmen. Close communication with men, better methods of handling, and the infusion of good blood from the Eastern States and Europe, are all producing great changes, while the wonderful quality and endurance of the native stock are retained. Bred in mountainous regions, at an altitude of from five thousand to ten thousand feet, accustomed to fend for themselves, they are a survival of the fittest. So hard is their lot in winter that it is not uncommon to find many of them with the tips of their ears frozen off. My experience of range horses is that no idea of their quality can be formed by looking at them from a distance; it is necessary to get close up to them, to get into the middle of a herd of them, to sec the strength and stoutness of back and loins through their roughness. They require handling with caro at first, but they are readily broken in. In estimating the potentialities of the U.S.A. for horses for nilitary purposes, the range horses must not be lost sight of. They are an improving stock, and moreover they have cheapness for their recommentation. Quite a large number of them were bought by our Government during the Boer War. The United States is often supplied with them for cavalry, and quite often branded horses are found in export stables.

The enormous trade in horses is done through stock yards or markets in large towns. The principal are Chicago, St. Louis, Kansas City, Onialia, Buffalo, St. Joseph, Indianapolis, and New York. The rapidity of sales by auction is remarkable, and the American auctioncer, a lighly-paid man, is a revelation in expertness. An auction is quite one of the sights of the United States. Over 600,000 horses and mules are received at the different markets anmually, and 225,000 head of loorses are said to be sold, 25 per cent. of which might be classed as good.

Chicago (receiving 100,603 horses and mules in 1903) is the largest horse market. It is the best for drauglit classes, and the centre of export trade. The stock yards stables cover 100 acres, and will accommodate 6,000 horses. I attended a sale there in February last, and saw a good stamp of medium draught horse, suitable for agricultural work, parcel vanners, etc., sold, the average price being 150 dollars. It is not such a good market for saddle horse classes:'

St. Louis (receiving 107,883 animals in 1903, of which $45 \mathrm{pcr}$ cent. are mules), Kansas City (recciving in 1903, 63,437 animals) are better markets for these classes, particularly the former. By noting the receipt and shipment returns with regard to railway lines employed, it is easy to determine the states from which the animals 
come and the States to which they go after purchase. Transportation of stock is admirably arranged; excellent stock-cars, to hold from 20 to $2 \overline{0}$ animals, are used, and a State law necessitates the unloading of all animals in transit for water and food every 28 hours.

Omaha is a market for range horses. Buffalo and Indianapolis are really feeders for the retail markets of eastern cities. Many horses in their journey cast pass through several markets.

Prices of horses have gone up nearly 20 per cent. in the last two years. Mounted infantry cobs that cost us 85 dollars during the war, would cost us now 100 dollars at least. Cavalry horses, sold then for 100 dollars, would bring now 125 dollars. Horses suitable for artillary purposes were selling at St. Louis, on my visit in February, at from 135 dollars to 147 dollars. In Chicago prices were a little higher. On the whole, I thought St. Louis a more reasonable market.

The prices paid by the American Government this year for Army purposes were:-

$$
\begin{aligned}
& \text { Special riding.-220 to } 300 \text { dollars. } \\
& \text { Cavalry. }-147,149 \text {, and } 155 \text { dollars. } \\
& \text { Artillery.-167 and } 170 \text { dollars. }
\end{aligned}
$$

The rise in price is due to increased home demand for good horses, and to export. The total annual export in ordinary times is well over. 60,000. Canada is the principal customer at present, and it is computed that her requirements this year will amount to at least 40,000 , mostly of an agricultural stamp.

The export to Europe, chiefly to the United Kingdom, shows a falling off; 80 per cent. of the export is done through Chicago, and is chiefly of the light draught class-parcel vanners, 'busers, and carriage horses.

The British Government during the Boer War purchased 107,511 horses and 80,524 mules. The system of purchase adopted was the placing of orders with approved agents. To purchase at auctions would have been impossible. The purchase grounds lay chiefly west of the Mississippi, and the horses selected were almost entirely of the riding classes. They were very favourably reported on in South Africa, particularly the mounted infantry cob.

Though my paper relates only to horses, I am loath to close my altogether inadequate remarks on the U.S.A. without making mention of the $\Lambda$ merican mule-peer of mule kind-the most handsome, hardy, useful, and satisfactory animal extant, and of greater average value than horses in his own country. From the small miner, 12.3 to 13 hands, to the magnificent heavy sugar mule, 16.2, he is bred in Missouri and contiguous States, also in Texas, and his market is for mines, lumber trade, and the cotton and sugar fields of the soutl. I take off my hat to the St. Louis mule that was regularly hunted with one of our best English packs some few years ago. Truly, he was worthy of the honour of a pink coat.

To-day there are about $2,750,000$ mules in the United States. The British Government purchased 80,524 for South Africa during the war, and the supply was going strong at the end.

\section{Mexico.}

I may pass over Mexico with a very few remarks. From a remount supply point of view, the country cannot be considered of 
any practical value to us. The equine products, Spanish in origin, are ponies of the average height of 13 to 14 hands, occasionally runuing up to 14.2. They are light, shelly beasts as a rule, value £5 to $f 10$, but very hardy and good stayers. The best breeding States are Jalisco, Michoacan, and Morelos, though all along the valleys of the Sierra Madre, in Zacetecas, Durango, and Chihuahua, breeding obtains, though not with any real discretion. The Mexican cavalry are to a great extent mounted on imported United States horses of a cheap and inferior standard, and the carriage and ridiug horses of the better class of people are imported.

\section{Argentine.}

Of the South American Republics, the Argentine is by far the most important, containing 4,500,000 horses. In point of numbers it is very rich and resourceful, but I am sorry to say that the reputation the Argentiue horses enjoyed in the South African War was not of a savoury character, and experience of them showed that they were not equal to the vicissitudes of a campaign. Soft-hearted, incapable of effort, lacking in stamina were the common reports of them. This is disappointing, because in their own country the Criollio, or small native horses, bear a good name for endurance, going long distances without being exhausted. It is an acknowledged fact that they will canter a distance of 80 to 90 miles a day carrying a man and a recado (native saddle reighing 60 to $100 \mathrm{lbs}$.). This may be true of some, but the fact remains they did badly in South Africa, so badly indeed that purchase was suspended in October, 1900, after about 26,000 had been bought. This failure is moreover unfortunate, as the country offers a good and ready field for large numbers of animals of the mounted infantry and light cavalry stamp. Various reasons have been assigned for the failure, such as "want of acclimatisation," "lack of stamina or 'bottom," partly inherent, but also consequent on the heart-breaking methods of breaking-in, and an entire subsistence on a grass diet. I am strongly of opinion that the last was the cause. I do not think that any entirely grass-fed animal is fit for the active service of a campaign. And of all horses I have ever met, the Argentine is by far the slowest at taking to a grain diet. He will sulk and leave it for days. I accompanied a shipment from Buenos Aires to Durban in 1898, and $I$ well remember the difficulty we experienced in this respect. They would eat alfalfa by the ton, but would turn their noses up at our trials of oats, bran, and maize. Another feature of the Argentine horse is. that he is a very home-sick animal. Take him from his friends of his Tropilla, and you find him grieving at the change for a long time afterwards. Many of the Criollio horses are badly coloured animals, with blazed faces and four white legs-always, to my mind, indications of a soft and inferior tred animal.

The Argentine horse is essentially a riding horse, and for riding purposes he is chiefly used in his own country. He may be divided into two classes-viz., the Criollio, or native bred, and the Mestizo, or crossed bred. The former is by far the most numerous, and is the usual or common horse of the country. Out of the total number of $4,500,000,4,000,000$ are Criollio. Their height is from 13 hands to 14.3. Whole herds exist on different estancias. Geldings are the most valuable. Mares are not used for riding purposes. The latter 
are usually small and mean, menadas or herds, of them running vild with an equally wild stallion, and they are only brought into corrals when the young horses are to be branded and castrated. All animals are branded with the mark of the owner, usually on the near thigh, sometimes on the neck, and often the brands are unsightly. The best and biggest are to be found in the provinces of Buenos Aires and Santa Fé, on account of better grazing grounds. They are smaller in the provinces of Cordoba, San Luis, Rioja, Tucuman, and Salta, grass being indifferent there, and many parts being mountainous. In the provinces of Entre Rios and Corrientes numbers are lired, but these provinces being low and wet, they have very flat feet, and they are not in favour in consequence.

The number purchased by the Commission from November, 1899, ts October, 1900-viz., 25,932-would appear to be about the available amnual supply of trained animals. They would be suitable for mounted infantry or light cavalry. If unbroken animals, or potros, were taken the supply would be much increased. The value of broken animals is from $£ 5$ to $£ 8$.

The Mestizo is the result of the foreign stallion and the Criollio. mare. The main reason for the introduction of foreign blood was the desire for horses suitable for carriage work. The haut monde of Buenos Aires rejoice in their turn-outs, and a first-class horse is worth almost as much there as in Europe. The imported stock consists of English thoroughbreds, hunters and hackneys, Anglo-Normans, Arabs, Morgans from the United States, Trakelnens, Oldenburgs, Ilanoverians, Percherons, Orloffs, Clydesdales, Shires, Clevelands, and Suffolk Punches. 415,000 of the horses will now be Mestizo. Out of this a very limited number could be obtained for artillery purposes. The Commission in 1898 purchased 120 fair specimens, chiefly crossed English strains, and obtained from English estancieros.

Much attention has been paid to the breeding of thoroughbreds for racing purposes. The racecourse at Buenos Aires is worthy of a visit. A glance at the race-card will soon make one acquainted. with the best thoroughbred strains and studs. Ormonde, it will be remembered, went to the Argentine, but was returned. Orville (son of Ormonde), Phonix, and Whipper were other English importations. Some very useful Argentine thoroughbreds have raced in England, and previous to the war several did well at Johannesburg and other race meetings in South $A$ frica. Speaking of Ormonde in connection with the Argentine, two of his grandsons (through Orville) were purchased as troopers by the Commission in 1898, and served in the ranks of the 7 th Mussars at Maritzburg.

In concluding my remarks on the Argentine, I should like, as a humble member of the Commission of 1898, to mention the pleasant associations we had with Señor Don Manuel Quintana, now President of the Republic.

\section{Cinile.}

Chilian horses have a great name for hardihood. They are similar to the Argentine, but stronger-looking, better broken, and more care is taken of them. Being bred in a hilly country, they are clever in getting up and down hills. Some of them were purchased by the Argentine Commission in 1900; they travelled well to the port of Buenos Aires, a long distance, but they were mixed up with the Argentine horses and suffered in the generai condemnation. The 
supply would be very limited. The best are progeny of the Chilian mare with English thoroughbred hackneys and Clevelands. For driving purposes in Valparaiso and Santiago the Cleveland bay has been mostly bred and used during the last 30 years.

Penu.

Chile supplies Peru with horses for its Army and police. Revolutrons prevent any breeding in the latter country.

\section{URUGUAY.}

Revolutions also interfere with breeding in Uruguay, though the country contains a fair number of hardy, snall mustangs, or Criollio lorses, said to be hardier than Argentines.

Paraguay.

Paraguay is not a loorse-producing country.

\section{Brizil.}

Brazil is too encrvating to produce anything but undersized and sluggish animals, excepting perhaps in the south near Uruguayan bordc: The country is of no practical good from a remount point of view.

\section{British Eurine.}

I fear that the recital of so much dry fact relating to the foregoing countries has already wearied you, but I crave your indulgence a while longer in a question that should concern us greatly, which I have purposely kept till the last, and to which I feel that wiser and more experienced heads than mine could do better justice, viz., the resources of the British Empire in horses.

Being pre-eminently, as a nation, lovers of lourses, obscrvant travellers in our dominions, and soldiers having scrved in our various Colonies, I assume that the majority of us here to-day are fairly well acquainted with the horses of different parts of our Empire, and that I may therefore be spared much minor detail with regard to breeds, classes, etc., and deal more fully with the more important consideration of resources and supply.

Commensurate with the other Empires and countries, we are sadly deficient in total numbers of horses.. I wish particularly to cmphasise this. For the whole of our Empire we have only about ' $8,000,000$. In comparison to this I will only quote two countries, viz., Russia, with $23,000,000$; the United States of America, with 17,000,000. (N.B.-The U.S.A. census of 1900 says 21,000,000.)

Our 8,000,000 are distributed as follows:-

\begin{tabular}{|c|c|c|c|}
\hline The United I & Kin & & 3, \\
\hline Australia & - & - & - $\quad 1,62 \overline{5}, 000$ \\
\hline New Zealand & - & - & 287,000 \\
\hline India & - & - & $-1,343,000$ \\
\hline Canada & - & & $-1,500,000$ \\
\hline South Africa, & including & $\mathrm{Na}$ & - $\quad 250,000$ \\
\hline Jamaica & - & - & 47,000 \\
\hline Mauritius & - & - & 12,000 \\
\hline Nialta & - & - & 8,000 \\
\hline Newfoundland & $d$ - & - & 6,000 \\
\hline Ceylon - & - & - & 4,000 \\
\hline Falklands & - & - & 3,000 \\
\hline & & & \\
\hline
\end{tabular}




\section{United KingdoM.}

The shortage does not relate in any way to our small Unitod Kingdom, truly, the Mother Country in the matter of horses as well as in other affairs, where not only the horse population is very dense-about 23 to the square mile in England, 20 in Wales, 6 in Scotland, and 17 in Ireland-but where the best horses of all kinds in the world are produced, horses that are sought after by every nation in the world for breeding operations and improvement of stock. It is quite unnecessary for me to descant on the superiority of our English thoroughbreds, the excellence of our hunter half-bred stock, the magnificence of our heavy draught horses of Clydesdalc, Shire and Suffolk'Punch breeds, the merits of our hackneys, and the hardy races of ponies of Dartmoor, Exmoor, Wales, and Connemara. Tolumes have been written about them all. I would, however, like to mention that we do not appear to know rightly the number of horses we have in the United Kingdom, or at least in Great Britain. The number, 3,000,000 quoted by me, is only approximate guesswork. I think it speaks rather badly of whatever Department is charged with the census of animals that more reliable data are not furnished. The Board of Agriculture Returns, which enumerate agricultural horses only, leaving unnoticed the horses used in commerce, trade, etc., give a total of about 2,011,000. Our Army horses number 33,172 (estimates 1903-4), and a fair computation of 955,000 for horses engaged in commerce, trade, etc., would make the approximate number up to $3,000,000$.

It is in our Colonies that we are deficient in horses, not only in numbers, but to a great extent in quality, and to this our urgent attention is demanded. We require greater numbers there; we are in need of better fields of supply in times of need, enabling us in such times to be independent of other nations, or at any rate, to first draw on our own Dominions, giving them our custom.

We have had the experience of a war where, in addition to the lorses of troops previously existing in South Africa, 470,000 horses were utilised. Out of this number, about 311,000 were brought over sea, having been purchased by Remount Commissions. These comprised 76,830 from the United IKingdiom, 38,147 from our Colonies of Canada, Australia, New Zealand, and India, 196,807 from other countries.

Though perhaps unavoidable at the time, it scems a pity that so much of our patronage should have been bestowed on countries outside our own Dominions. Had we then given more of our custom to our Colonics we should be reaping the good results now in increased production from the stimulus given to lorse industry. However, it is never too late to mend, and our past experience demands that we should put our house in order. The question is, how is this to be done? What are the steps that we should take to better our position and provide for the future? Much has been said and written about Govemment studs, and the costly methods of the Continental Powers have been lauded and held up to us as cxamples. We are much too prone to accept the view that methods in practice on the Continent are superior to our own. I venture to assert that the average British farmer will give points to any Government brecding establishment on the Continent in the matter of breeding of horses and the stock raised. Why do the Continental Powers come to us 
in England and Ireland for horses if it were otherwise? Individual taste and a market are the chief factors of production, no matter in what country. Without there is a demand there is no supply. There can be no demand without there is population. Take the United States of Amèrica, for instance. Here there is a large population which is day by day increasing, not only in numbers, but in prosperity, and there is a corresponding increase in numbers of horses required for trade, agriculture, pleasure, etc. A market is thus created, and it is of no profit to breed any kind of horse but a marketable one. This fact is also well illustrated in Ireland. Here we have, roughly, 580,000 horses, and an export of 25,000 anuually. We find representatives of every country coming to Ireland,' whose horses are essentially of a riding and light draught type. A market is thus maintained, and you have supply to meet it. We hear a terrible outcry that the foreigners take the best horses out of the country, and that we ought to take steps to prevent this. I affim this is a mistake, and I assert that they do good instead of harm by their coming; and I am of opinion that we should encourage them to come, and ask their friends to come, because they create a market, and an improving market, which will always redound to our profit and advantage. If at any future time, when there is urgent need, the horses will be there, and we will have first call.

Government can, however, do great good by supervising the breeding of horses, having in view the particular class of animal required. To me it seems that too much attention is paid to stallions and not enough to mares. This supervision is much more necessary and important in our Colonies than in our own older country.

\section{Canada.}

We have in Canada a great possession, and $I$ am sanguinc as to its future as a ficld for supply. Everything is in its favour-cheap lands, which are essential for profitable production, an increasing population creating a demand, and prosperity, which will insure a good market. Our Canadian brothers are eager for custom, and would hail with delight and satisfaction any patronage which the Mother Country could give them, even to a small modicum per annum, for the Army. To illustrate this in a simple way, I should like to inention an incident which cane under my personal notice when in Canada this year. $\Lambda_{n}$ order had becn received from the Home. War Office for the purchase of a few black horses for the Houschold Cavalry. Visiting a $s$ mall agricultural town in Ontario for this purpose, I heard a man making enquiries where he could obtain the services of a black stallion, and on being asked why he required such, he answered that he had heard the British Government were going to patronise Canada for the purchase of black horses, and he had decided to commence brecding to that end right away.

At present, however, with the cnormous influx of population into the country-which this year will total at least 250,000 - particularly into the north-west territory, there is a great home demand for horses, more than the country can properly meet, and large numbers are being imported from the United States. Probably 40,000 will have been imported this year, as compared to 29,000 last year, and 18,000 the year before. 
This is a sign of good times. It is only to be hoped that for the future general stock of the country, care will be exercised in the selection of mares for breeding purposes. The standard of suitability of the sires can be relied on. At the same time, if the call came, Canada would always find ways and means of furnishing us with a fairly good number of horses, whether in peace time or in war.

During the Boer War, 14,611 horses were drawn out of Canada by the Remount Commission. It would be difficult to obtain the same numbers on emergency at the present time. One competent authority estimates the supply of good suitable horses for Army purposes at 2,000 per annum, the chief number being obtained from Eastern Canada. However, if the Nortl-WVest and British Columbia were exploited, I am confident this number could be increased. The type of horses in Canada has considerably changed within recent years, especially those of the North-WVest. An agricultural type is now in greater demand, and horses suitable for the riding branches of the Army are not so rcadily obtainable.

The advantages of the contiguity of the United States to Canada, moreover, must not be overlooked. This cnlances the value of the latter as a base for remount operations in case of a very pressing demand, particularly as regards the mule, which Canada has not got.

Furthermore, in the event of war, whether in Asia, Europe, or South Africa, the country is not inconveniently placed. Every facility for shipment east or west exists, and trans-continental transportation is easily effectod.

\section{Australia.}

It is much to be regretted that the reports on the Australian horses during the war were so disappointing. We expected better results, considering the character they bore as remounts in India, and especially as they were Southern clime animals. The shipments at the commencement of the war were satisfactory, but towards the end, when the work to be done was much more severe, they were found wanting, and were the subject of much adverse criticism. Apparently the good stock of the country had been exhausted, and the supply was, in later times, drawn from inferior productions. It is feared, and it is greatly to be deplored, that the quality of horses generally has much deteriorated during the past few years. The attention of landowners is directed to the much more paying industries of sheep and cattle raising. There is no money in horse-brecding, the demand is small, and consequently there is a decay of production, especially witl regard to useful horses. Racing is much in vogue, and the breeding of swift thoroughbreds for short, fast races is resulting in the production of many weedy animals, having a bad influence on the future stock of the country.

I am certain that all of us who have served in India and cultivated there a liking for our friend "the Waler," were grieved at the bad reports on him in South Africa. Personally, I have the greatest love for Australian horses; I was much associated with them during the six years of my service in India, and $I$ have no hesitation in saying, that the horses of the Horse Artillery there are second to none in the world-at least, this was so in the nineties, when I knew them. I may say the same of the medium cavalry and liorses of the charger and hunter type to be found in the private market, the latter always 
being worth 1,000 to 1,200 rupees. I should like to say so much and more in defence of Australian horses. I trust that the falling of in standard and the condition of the horse industry generally is not se serious as has been reported, and if it is so, that the stimulus which the requirements of the Boer WVar no doubt created will be productive of good results, that closer attention will be devoted to useful-looking animals, and that all nondescripts will go to the wall. We cannot afford to allow so good a field of supply to lapse, or to suffer one so conveniently placed to India and the Eastern portions of Asia to fall into disuse. I look upon it as fortunate that the country has in India so good a customer in normal times for both private and public horses. A depreciation in its annual customwhich amounts to about 6,000 animals-would have a serious effect on Australia.

The order towards the end of the war for small, compact horses from Australia and the failure to find such was rather interesting. The general run of horses of the country, at least in Victoria, $\mathrm{New}$ South Wales, and Queensland where the best horses are bred, are of the tall order; small horses are very much in the minority, and I think the name given to the latter when purchased in India for native cavalry regiments for 350 rupees, aptly describes them, viz., "Bounders." We' all understand the term.

It was unfortunate that during the war Australia was suffering from a very severe drought, probably the worst ever experienced. Large numbers of horses were rejected on account of bad condition, and even in those purchased the condition was not satisfactory. However, we may put down the following as the capabilitics of supply of horses suitable for military purposes of all kinds-ages five to nine, and broken:-

800 per month from New South Wales.

400 per montl from Victoria.

750 per month from Queensland.

500 in two months from South Australia.

700 in four months from Western Australia.

450 to 500 in two months from New Zealand.

\section{N'EW Zealand.}

The horses of New Zealand resemble English horses, and théy are generally nicely broken, but the numbers available are not great.

In concluding my remarks on Australia and New Zealand, I should like to mention a fact which I consider of great importance with regard to Army supply. There are certain men who have had the experience of many years' shipping loorses to India, most of whom have had to buy this experience dearly. These men should always be utilised. They know Army requirements to a nicety, and can usually submit horses for inspection in India without many rejections. New men coming into the trade invariably have horses left on their hands as unsuitable, and so lose money.

\section{INDIA.}

A few paragraphs back I remarked that it was fortunate that Australia had in India a good customer, and that a withdrawal of this custom would have a detrimental effect on the horse-breeding 
interests of the former country. I particularly ask you to consider this in the light of the horse-breeding operations in India. These operations, which were commenced in 1876, on the abolition of the old Stud Department, have sought for the ultimate object the production of animals of sufficient size and substance to meet the requirements of the Army in India, not only for cavalry, but artillery, and to render that Army independent of foreign markets. Time will rot admit of my entering into any description of these operations, very commendable in themselves, and it would ill bccome me to comment on the controversy and divergence of opinion expressed relative to the merits or otherwise of the English and Australian thoroughbred, Arab, hackney, and Norfolk trotter sires used for the grading up of the native stock. The object has not becn achieved, and the artillery horse, the raison d'etre of the Norfolk trotter, has not been forthcoming. India will produce horses readily enough, but the climate and conditions of life militate against size and substance. It lacks the green grass and grazing necessary to grow sizeable stock, and the introduction of coarse strains of horses for breeding purposes only makes matters worse. We do well enough to rest content with the excellent pasture lands of Australia for our Indian Army supply of artillery horses. The best of the stock raised in the country under the Horse-Brecding Department is taken at a young age into the remount rearing depôts for better care and feeding till fit for issue to regiments; about a thousand per annum are thus obtained. Certain native cavalry regiments have their own studs: the 11th Lancers, for instance, have been very successful in breeding their own remounts.

The attractive prices given for polo and racing ponies has resulted in production towards this end. The general purpose animal is a pony, and the majority of the animals of the country are of this class. It is satisfactory to note that some of the old breeds, such as the Beloochi and the Kattiawar, are being revived, and we must not forget the sturdy, hardy, small Burmese ponies, to improve which by any foreign importation would be absurd. The resuscitation of these hardy breeds of small horses, and the encouragement given to their production to better type, is certainly a step in the right dircction. The more useful animals we can stock the country with the better, and to this general end the horse-breeding operations cannot fail to be conducive to great good. In any war in India it will be found that the animals bred in the country, no matter of what size and substance, will stand the vicissitudes of a campaign much better than imported material. It can never be said of India that it is a country in which foreign animals quickly acclimatise. The enervating influcinces of climate are against this. So let us take care of our riative and country-bred stock and grade it up to a better standard generally, in view of the greatest possible supply in time of necessity. Even the Gharry and Eklia ponies and the grasscutters' tats should not be overlooked. Frontier warfare would require a large amount of pack and light draught transport, and the small animals are the best to perform this, be they ponies or mules.

The Indian Army in times of peace requires nearly 3,000 remounts. These are furnished from country-bred stock and importations from Australia, Arabia, and Persia, light cavalry being mounted on country-breds and Arabs, medium cavalry on Australians, and the 
artillery being horsed by Australians. In times of active service, the country, with its $1 \frac{1}{2}$ millions, supplemented by the more easily acclimatised $A$ rab and Persian horses, would be equal to the mounted branclies of the Service. Broken horses of a mature age from Australia would supply the wastage in Horse and Field Artillery, and early purchasing could be so arranged to admit of a reasonable time for acclimatisation. A good number as a reserve is usually maintained in depôts, and this would be first drawn on. The large livery stables in Calcutta, Bombay, and Madras would also be in a position to furnish a few. The experience of one war in regard to required numbers and classes of liorses is no criterion for the next, and it is very improbable that any war in and around India would result in the vast wastage of horseflesh that was experienced in South $\Lambda$ frica during the Boer WVar, at least, in regard to riding classes.

\section{SoUTH AFRICA.}

This brings me now to the consideration of South $\Lambda$ frica. The war left tho whole country in a very denuded state. Previous to hostilities there were 387,000 horses in Cape Colony alone, 54,000 in Natal, and a very considerable number in the Freo State and Transvaal, chiefly of a light cavalry, mounted infantry, and light draught type, excellent small animals that withstood the hardships of the campaign better by far than any other horses. The mortality in horses during the war, I may mention, is roughly estimated at about 340,000 . To-day probably 250,000 will cover the total number in all the States, but we have left as a legacy the chance of the world in establishing a race or races of horses, an opportunity the like of which has never before been presented to any country, and which now rests in the hands of administrators to make or mar. It is a case of begimning again, but the beginning is replete with great possibilities. With a foundation stock drawn from the best countries in the world, and a country pre-eminently suited in climate and soil for the raising of good, healthy, hardy animals of any type, I cannot imagine a fairer promise. It is to be hoped that future prosperity will mature this promise, bringing success to the horse-raising industry, and that in time our dominions in South Africa will show us in horses an asset of Empire, the real value of which can best be apprcciated when there is a call to arms.

I trust that it will not be thought for one moment that I hold a brief for the colonies, and favour them in preference to our home markets. The major portion of the mounted branches of our standing Army being located at home, the demand in time of peaceviz., about 3,000 por annum-can readily be supplied locally-Ireland for cavalry liorses chiefly, and England and Scotland for draught purposes, but for active service abroad we must go further afield.

\section{Registration.}

To meet the immediate requirements on mobilisation we have registration of 20,000 trained horses of different kinds at 10 s. per horse per annum, most of which number belong to the large commercial firms in London. There is a diversity of-opinion as to whether this registration is worth the cost, and whether, by offering a good price when mobilisation is required, horses could be obtained from large firms just as easily without resorting to the enormous expendi. 
ture entailed in registration. In any case, there would appear to be nccessity for modification. It is possible that registration might be made general throughout both Great Britain and Ireland, that it might be done through county and municipal authorities in conjunction with officcrs appointed by each army corps or command. This registration would show classification as to suitability for each branch of the Service as far as possible, and it need not interfere with the floating horse population of export, sales, etc. By this means also contagious diseases in horses would be licpt in good control, if not cradicated altogether. Necdless to say, no retaining fee for registration would be paid; but the alternative of a good price could be relied on to induce owners to sell when mobilisation was required. The main thing is to know where the horses are.

In bringing this lecture to a close I fear I have left unsaid things that I might have said, and that $I$ have been very indefinite on many points, but $I$ found as time rient on my notes were getting very voluminous, and that $I$ must either abridge them or begin again on narrower lines, avoiding technicalities: I chose the former, but I trust my shortcomings will be overlooked, and that any important omissions will be supplied by discussion.

Sir, I thank you for the honour you have conferred on me by talking the Chair; and, gentlemen, I also thank you for the hindness and patience of your attention.

Major-General F. W. Bexsox, C.B. (Director of Transport and Remounts):-In opening this discussion, I mill not take up your time, as it is getting late in the erening, and there is hardly time to enter into the discussion of the merits and demerits of the various classes of horses which Major Moore has mentioned in his lecture. I should like only to draw attention to the fact. that I am afraid we ought not to draw conclusions from the experience of the South African War, as regards the horses that were in use there. As you know, there rere so many factors at work, such as the change of climate, change of food, the rapidity with which they were turned into the field, the want of horso managenent, and other matters, which render it very difficult to come to a judgment regarding the horses. That is to say, it rould be unfair on the countries from which we were obliged to draw our supplies if wo jump at a conclusion. founded only on the experience of that war. I observed in the Times that there was an article on "The Transport of the Japanese Army," and I read that article with great carc. The subject was mentioned the other day in a lecture, and reference was mado to the type of transport animal used by the Japanese. It was rather hinted that we ought to take a Iesson from these wonderfully small and curiously shaped, ugly animals, which were used there. When I read that article, I did not come to that conclusion at all. The article did not say very much about the trpe of the animal; what it did say, was the manner in which the Japanese used them, and that is the lesson for us. Instead of asking the pony to do half as much again as he could do, they asked him to do only half what he could do, and the result has been that this little animal has worked in the wonderful may in which it has. I think, if we rould reduce our loads both on top and behind the horse we should get a great deal more out of the arerage horse than wo do at present. It is, not to be expected of any animal, howerer good he may be in the hunting ficld or anywhere else, that if ho is over- 
weighted, or has too heary a load behind him, he can show all that is in him. Our mastage would haro been very much less, I am certain, had there been more care taken in the management of the horse himsclf. I endorse what Major Moore has said about Canada, as $I$ am in a position to know something about that country, being a Canadian myself; but we must always remember when we are dealing with our colonies that wo must bo fair, and, as far as possible, just to them all, and also bo just to our own brecders at home in Great Britain and Ireland. Howerer, there is no doubt about it, that Canada offers a rers excellent market for the future, and it is to Canada we shall have to turn for a great proportion of our horse supply in case of emergency. I hope that the timo is not very far distant when we mas hold out some practical encouragement to Canada in the way of some sort of annual supply, if possible, whatever it may be, and perhaps we may do the same for our other colonies.

Colonel P. H. H. Massx (Reserve of Officers, late 6th Dragoon Guards):--I must apologise for saying anything, having becn so long separated from our home service, employed abroad, but still, I think I may add a few words. First of all I may allude to the fact that tho Duke of Deronshire, speaking two days ago at the Bakerell Farmers' Club, mentioned that our light horses were not what they were expected to be; they had not improred at all of late sears. I think our Gorernment should do something to improre horse-brecding, by taking the matter up. Major Moore, in his admirable lecture, has pointed out to us that in nearly erery other country in the world the Government talies up this question, and, if not entirely taking the matter out of the farmer's hands, at least assists him. This might be done in Ireland and South $\Lambda$ frica, especially. In Ircland we have an admirable horse breeding country. We might, I think, hare a system of Government stallions serving approved mares, which would entirely mect with Major Moore's notion of selected mares, at very low fees, and then we might have remount depotts to which the young stock, on being bought, might bo sent. Instead of being purchased, as now, at four or firo years, they might be obtained as threc-year-olds, and put into depôts, being taken in hand at four years and trained gradually, and sent to corps at fire years. They would then have got over their strangles, and would not cause the tronble they do nom, or talie up the same time in training them on joining units. The lorse rould be proportionately cheap at the sounger age. Tho Government would, of course, hare to take a certain amount of risk, but thoy would get the horse much cheaper, and have a considerably larger stock to choose from, as these horses mould not, at that age, have como under the eyo of the foreigner, who is a great buyer of horses. I think if this system were adopted, the chicf thing would be to carry it out on a very economical scale. Very often wo do things on a large scale, building largo barracks, for instance, and then finding that the system does not answer we have to throw it up. It would be better to haro only light stabling or sheds, to turn young horses into. Jand in the west of Ireland and South Africa might bo used, where it can bo purchased very cheaply, where we could turn young stock out, and bring them in during the last year. I have visited Government studs in IIungary, and it is a very interesting study. Ans officer who takes an interest in the question mould do rell to take a run over to Hungary, and when lie arrives there the officers in charge will be only too happy to slow lim the Gorẹrument studs, which aro carried on at 
comparatively very little expenditure. The system has been explained by Major Moore. In Bulgaria; whero I now am, a great deal has been done by the Government, and I should think the horses of that country have been improved a hundred per cent. When Turkey left Bulgaria some 20 years ago, the horses were very poor. The Bulgarians havo now bought stallions, and hare got good mares into their studs, and they turn out these mares, selling them rather cheaply, putting stallions at certain centres during tho covering season, and the whole breed of horses in Bulgaria has considerably improved. $\lambda$ s to the purchasing of horses abroad, as Major Moore says, the local agent is generally the best man to employ under proper supervision. If one sends out a man from lome who does not understand the country or its language, he very often buys worthless beasts at an expensive rate, as wo did in Hungary during our war. The local Goremment will always assist when you aro buying in a foreign country, and it rould be best, I should think, to put oneself in their hands. Tho Hungarian horse, which, I think, was not so very successful in South Africa, is an excellent animal in Hungary itself, whero you can get for $£ 10$, what we bought, I fancy, at about £30 during tho war. In conclusion, I would adrocate buying horses younger than we do now, turning them into cheaply-built remount depôts, having a certain number of stallions at low fees to encourage lorse-brecding, and beforo young horses are sent to corps allowing their strangles to be over, and giving them a partial training, for which Iatter duty Reserve men might bo employed. I should say nobody is more competent to cleal with this question than our present Quartermaster-General, an acknowledged horsemaster and rider. With regard to Major-General Benson's remarlis as to the weight carried by our troop horses being excessive, in which I quito concur, that light carts might be used so as to take the weight of a heavy lit off the horse's back, and something in that way I think should be done.

Mr. W. S. SrMik :-I have listened with the rery greatest interest to the paper read by Major Moore. I had the pleasure of mecting Major Mooro and Colonel Lawley in Toronto, when they were there on the vers business you have heard him speaking about, and I am pleased to find that ho speaks well of the Canadian horses, and that ho thinks some encouragement might bo given to that colony in future by the authorities at homo. Ho has also spoken of the foreigner coming hero and buying your horses, and he says that he welcomes the foreigner. I am sorry to say on this point that I entirely disagree with him, for this reason, that tho foreigner will not talio your geldings. He takes your best mares, and at every fair-I have linown it for years-tho foreigner comes and picks the best mares, and that is one of tho reasons why your farmer is not brecding so many horses as ho used to in olden times. We have felt this in Canada. You see here in London the best class of horse in any numbers that is to be seen in the rorld, and that is the London General Omnibus Company's horses. Wo have felt in Canada that there are a great many of them bred by us, and the people in the States come to buy as well in order to sell to the General Ommibus Company. I have told our farmers over and over again, "Keep your mares and sell them your geldings." To are suffering now from that very thing, that the foreigner has come and taken our mares. There is a very great deal moro in that than meets the eje at the moment. It is the future you have to look to, and without good mares, as Major Moore has said, you cannot possibly get good animals. We have plenty of good stallions. 
With regard to the encouragement he speaks of, that might bo giren to Canada, I was very pleased to hear from Major-General Benson's lips that there is just a possibility that somo encouragement might be given. Gentlemen, we are waiting for that encouragement. Wle have been waiting for that encouragement for some time. Wo have a million and a half horses in Canada, and I venture to say that the great majority of those horses are sound. That is a great thing to say. Wo do not get many curbs, side bones, spavins, and rery few splints. There is another thing in Canada which perhaps Major Mooro mas have noticed when there, namely, that it is rery seldom indeed that sou sec a brokenlineed horse. I do not think there is an average of tiro in a thousand. You could not find that here. That sliows you that the horso has been accustomed as a young horso to look out for itself over rough ground, and ho is very hearty and sound. Well, gentlemen, if you can possibly sce your way, through the influence you have here at home, to encourage our breeding, do so. Wo want to breed sou what you want. When we como to England to buy machinery they say to us :- "Now, this has been in uso for 20 years; it is good enough for us and it is good enough for you." Gentlemen, it is not. Wo are willing to pay for what wo want. Wo want to proride you with the animals you want, and if you will give us a chanco by giving us an order, say, for 5,000 horses, spread over a period of ten years, we will try and biced to any type you may select. I lnow that the ranches aro really anxious to breed to the Army typo of horse, but they want some guarantee, naturally, that some of those horses vill be purchased for the Army. They bred these before, but they hare not found buyers of the $A r m y$ come orer for them. Certain men hare come to buy horses that sou wrere to pay 175 dollars for, and they wanted to buy these lorses at 75 dollars, and there were ten men getting 10 dollars apicce out of them. We do not want to do that trade. We want to give you value for your money, and if you will encourage us by putting such an order in tho hands of the Gorcrnment a qualified man will be found to buy the rery animals you.want, and in order to pay his salars-I put it very plainly hero-me will buy those horses at 7 dollars a head less than we charge you for then. That is the only commission that will come out of the deal at all, and I do not think His Majesty's Gorernment would object to that so long as they linow we aro honest. I do not want to sco a horse that is purchased for 75 dollars charged to you at 175 dollars. It is detrimental to the interest of the brecler; it is detrimental to the continuation of that confidence thit you have placed in us. I can only lope that you will give us some encouragement in Canada, and we will do our utmost to provide sou with the right class of animal.

Colonel J. A. Nuxs, C.I.W., D.S.O., A.V.D. :-Speaking about Japan, Major Moore mentioned that it was not quite known, except the Corca, where the ponies were brought from. When I was in Japan there was a very considerable trade done with ponies from Timur in the Malay Archipelago. I will not delay you talking about them, but I may mention that there is a rery good description of the Timur pony in Wallace's "Malay Archipelago." A detachment of Japanese police that I saw at a place in tho mountains were entirely mounted on them. They were hardy and rough little animals, and went rery well. There were a large number of Corean ponics brought into the country that were used in carrying enormous loads orer very rough roads. Major Moore nentioned that the barb in Algeria was only fit for mounted infantry purposes. It is some 
time ago sinco I was there, but when I was, the Chasseurs d'Afrigue wero entirely mounted on them. The Hungarian horse has been crabbed all round in the South African War. I was not in tho war myself, but some twenty years ago $I$ owned a Hungarian, and ho was as good a horse as over looked through a collar. However, ho was well fed and well looked after. My opinion is that the crabbing of the Hungarian horse in South Africa had more to do with the want of condition than anything else. $A$ speaker has mentioned about forcigners coming orer and buying mares, and it has been also mentioned that in tho breeding of horses too much attention is devoted to the stallions aud not enough to mares. For some years I was in charge of the horse-breeding operations in India, and there was an idea that any mare would do. I never believed in it myself, but I was acting under official orders and did what I was told. I alwass lnew it was wrong, and I think time has shown I was right. With regard to mares in Ireland, I can quite confirm what has been said. Long before I entered the $\Lambda \mathrm{rmy}$ I bred horses there myself, as I havo tho misfortune to be an Irish land-owner. I was not patriotic enough to keep them, and I sold them to the foreigners becauso they paid a better price for them than anyone else, and I have sold many a one to Germans and Iustrians. There is one remarl I would malse, and $I$ do not do it in any carping spirit. Major Moore has given a large list of figures. I presume tho ones relating to foreign countries and horso supply were only for comparativo purposes, because, in the event of this country being engaged in a serious European war, it seems to me that horses would be contraband, and those markets rould be closed. Regarding other parts of the world, my experience is that figures and statistics obtained about animals from Government sources and Blue Bools are utterly unreliable. I hare been on sereral expeditions of this sort, sent off to malse inquiries about horses and cattle. I have had statistics put into my hands, but when $I$ arrived on the spot $I$ found they were no use at all. As a rule, instructions come from tho central Government, and sone person, a consul or magistrate, is told to send in an estimate of the number of horses fit for mounted infantry, carriago purposes, ctc., also of bullocks for beef, cors for milk, and such like. He, in most cases, has no more idea what they are than the man in the moon, and if he had he is generally too busy to be able to do it, and the work is deputed to some subordinate, who usually does what he thinks pleases his employer.

Licut.-Colonel W. C. Underwood (late 4th Hussars) :-In the summer of 1891 I spent two months at Tarbes, the depot of the cavalry belonging to the district of the Hautes Pyrénécs. At that time a system mas cstablished of lending selected trooper mares to farmers and breeders from the ranks after the age of 14 , conditionally, that they should be put to Gorernment stallions (whose services wero granted free) and the foals to be sold as three-year-olds at a fixed price to the Remount Department. At the end of threo years theso mares become the property of the farmer or breeder, and ho is at liberty to sell any further foals at his own price. The mares are examined by the veterinary surgeon of the district halfyearly, to sec that they are rell fed and treated and not overworked. I was informed that the plan was a success, and had materially improred tho breed of horses in the Department. Why should a similar plan not be tried in Great Britain? In a preliminary trial, preferably in Ireland, little or no expense need be incurred. In these days, when so much is being talked about the encouragement of the depressed agricultural industry, here is an opportunity for the Government to do so, while improving the breed of lorses, increasing the reserve, and obtaining young 
remounts at a lower price. With regard to the colonics, if the authorities adopted the Cossack system in Canada or South $\Lambda$ frica a largo number of remounts might bo obtained. A Blue Book was published in $189.4 \mathrm{by}$ the German Intelligence Department, and translated by Captain Napier, of the Indian Amy, entitled: "The Cossaci Armies." A copy of this work is in the library of this Institution. From this book it appears that by assisting the Cossack colonists of the Ural no Iess than 60,000 Kalmuck horses are annually bred and sold to the Russian Government for troopers at $\mathbf{1} 12$ 10s. each as three-scar-olds. Gifts of land, freo use of stallions, and in some cases money grants, are made. If some of our Reservists were placed on lands in Canada (and I an officially inforned by MIr. I'reston, tho Canadian agent here, that tho Canadian Government have made an offer to our Government of free grants of laud) a large supply of troopers might be obtained as a reserve in time of war, whilo in peace time these settlers might be trained as the Cossacks are, forming an invaluable force to assist in the defence of the Empire. The Russians by this means obtain almost frec of cost a force of 500,000 men fully equipped from their Cossack colonies. All these facts are set out in the book to which I have referred. It may bo interesting to mention that from information supplied to me by Major-General Ileming, lato Military Ittachó in Japan, the Japanese are forming military colonies and breeding establishments in Yedo, the northern islaud. This probably accounts for the fact, which Major Moore mentions, that from Yezo the largest number of remounts in Japan are obtained. Quite apart from the adrantage which this plan would bo for increasing our supply of horses to an almost indefinite extent, it rould largely help to solvo tho problem of consolidating the Empire by supplying a large body of loyal British colonists.

Major J. Moone, A.V.D., in reply, said:-I have not very much to say in answer to the discussion. I know that the figures are not very reliable, but one must go on sonething. For instance, in the United States of Anerica I have put down 17,000,000 horses, but their orn Department of igriculture returns gave $21,000,000$. It is really one State competing against another in that case to seo which has the most animals. When I was in Mexico this year I had some of their returns, but they were hopelessly wrong. Still, I think that figures on the Continent may be relied upon. With reference to Japan, I mentioned in my lecture that it was not known where she drow her supplies from. I think I might have said a littlo differently from that, because I knew while I was in Canada that the Japanese wero reported to lave sent over an order for $\Sigma, 000$ horses to a man in British Columbia, but it was only a rumour.

Mr. Spink :-That order nerer came.

Major Moone:-I knew that during the China War they had horses from $A$ ustralia-in fact, they are custoners of $A$ ustralia. $\Lambda$ remark was made by Colonel Massy with regard to three-year-olds. Is a reterinary surgeon I say "No" to that. No animals go sick so much and go to pieces as the three-year-olds. The sickness and mortality are very heavy.

The Cuarmax (Arajor-General H. C. O. Plumer, C.B., QuartermasterGeneral) :- Is no ono elso has anything to say as regards this discussion, I am sure I shall be carrying out your wishes if I move a rote of thanks to the lecturer for his very ablo paper. Of course, time on these occasions is alnass limited, and we cammot get a rery interesting and able paper 
sead and a rery long discussion; but $I$ am rather sorry we did not get a littlo more discussion on this paper from what we may eall outsiders, not in any offensive way, but using the term to denote people not onticially concerned with the Remount or Veterinary Departments. I think one of the benefits of the lectures at this Institution is for us, who are officials for the tine being, to hear what is thought and said by those who are outside, and a little criticism, so long as it is not too serere, is very: good for us all. I am sure that all the facts and figures collected by Major Moore and read by him in this paper are not only of very great interest to all of us who have had the pleasure of listening to it, but will be really of permanent value to the Army. He has drawn your attention very clearly, as regards foreign countries, to the sums they spend annually on improving their horse-breeding and organising their horse resources for war. I think a little study of the amount of moncy spent in those countries will be rery instructive compared with the money which is roted by Parliament for our own purposes. Ho has described us, rery rightly: periaps, as being the nation that has not only the greatest love for but the greatest bnowledge of horses. To a certain extent I hope that is so; it certainly was so fifty years ago. But $I$ think we are apt to be a little self-complacent in that way. I. heard a critic say that as a nation the English talked more and knew less about horses than any other. I do not think that is fair, but still I do think we must remember that we are rather inclined to sit still while other nations are deroting a great deal of their time, a great deal of their moues, and a great deal of their resources towards studying lorses, and especially horses for war. We must all agree that in war our colonics must be our first lino of supply, and it is for us to create in peace time an organisation mhich will cnable our colonies to meet our requirements in war. Mr. Spark made some very interesting remarks about Canada. Of course, he does not expect me, I lnow, as Quartermaster-General, to answer him in this room. General Benson has indicated clearly that we are rery anxious to give encouragenent to Canada and the other colonies. It is not much good giving encouragement if it is only of a verbal or paper character. What is wanted is practical encouragement, and that means expenditure of mones. I can say this much, that the subject is receiring from General Benson and mysclf, and all who are working at it, very scrious consideration, and that we approach it in the most sympathetic spirit. The diffculties we hare to contend with with regard to the supply of horses for war is the variety of theatres of war for which we have to prepare. Horses will be alnost certainly required to serve under active service conditions, which are most arduous, in countries in which they are not accustomed to live, and, as one or two of the speakers have pointed out very truly, cine of the sources of our great wastage in South Africa lay in the fact that we had to use horses before ther could be acclimatised. We are now studying, and I think really studying (especially General Benson and the officers of the Remount Department), the question of what horses can be best acclimatised for serrice in different countries, and under what conditions. The lecturer has spoken of Canada, and Mr. Spark has told us a great deal about its resources and what thes can do. Major Moore has spoken in rery optimistic terms of the horses he found there, and which can be supplied. I should like to take this opportunity of saying that there is probabls no one better able to speak on that subject than Major Moore himself. He has visited the country lately, and in conjunction with Colonel Lawley, he has sent in a most valuable report. With regard to Australia, I do not think there is any fear of that country 
being neglected. It is to Australia that India must necessarily turu. Major Hoore has spoken of what India is doing in breoding horses. I think, without claiming for a moment any expert knowledge, there can b. no question that when horse-breeding is carried out in tropical climates like India, it is always the fact that in two or three generations there is a loss of bone and substance, and it is almost an inpossibility for a tropical country like India to keep up the supply of draught horses. For the supply of that class of horse, and for the horse required for tho liritish cavalry, I do not think thero is any doubt but that India will have to turn to Australia and New Zealand, and therefore those countries have really what may be called a perfectly certain market for them. As regards South Afriea, Major Moore has very rightly pointed out that that country las now a most exceptional opportunity of turning itself into orie of the finest horse markets of the world. Most of us lnow what South Africa has been and what South Africa is, and it all depends now on what the administrators are able to do as to whether the value of tho horses they turn out are not considerably enhanced. I happen to know that the matter is being taken up very seriously and rery practically. In the Orange River Colony, Sir Hamilton Gould Adams has been in coirespondence with us, and he has already taken out a large number of stallions with the riew to using them seientifically for breeding for Army purposes. I am quite certain that with all the natural advantages South Africa possesses the result cannot but be successful. We feel that in the future we must look rery greatly to South Africa, from its geographical position, for supplying us in the case of certain erentualities. I will not detain you any longer, but in moving a rote of thanks to Major Moore for his admirable lecture I should just like to say in conclusion that personally I owe a deep delt of gratitude to him. Ho was my veterinary officer in the early part of the war, when wo were operating in a part of the country where it was not easy to get horses, and haring got them there was very little reinforcement to fall back upon. I think I am not far out in saying that after a year of pretty hard campaigning wo handed over to the Remount Department something like 30 per cent. of our original horses fit to go on for many months, and that, in my opinion, nas due entirely to the care and attention Major Moore devoted to them. 